\section{СВІТЛІЙ ПАМ'ЯТІ ВИДАТНОГО ВЧЕНОГО ЮРІЯ ІВАНОВИЧА ГУБСЬКОГО}

\section{CHERISHED MEMORY OF THE FAMOUS SCIENTIST IURII HUBSKYI}

З глибоким сумом сповіщаємо, що 18 травня 2019 р. після тяжкої хвороби на 74-му році пішов 3 життя Юрій Іванович Губський - доктор медичних наук, профресор, член-кореспондент НАМН України, заслужений діяч науки і техніки України, завідувач кафедри паліативної та хоспісної медицини Національної медичної академії післядипломної освіти імені П. Л. Шупика, начальник науково-координаційного управління Президії НАМН України, завідувач відділу біохімічної фрармакології Інституту фрармакології та токсикології НАМН України. Перестало битися серце видатного вченого, прекрасного педагога, доброї та чуйної людини, вірного друга і хорошого товариша. Усі, хто працював і знав Юрія Івановича, залишать про нього найкращі та світлі спогади...

Профресор Ю. І. Губський у 1969 р. з відзнакою закінчив лікувальний фракультет Київського медичного інституту імені О. О. Богомольця (на даний час - Національний медичний університет імені О. О. Богомольця), його ім'я занесено в Золоту книгу пошани Київського медичного інституту. Протягом багатьох років науково-педагогічна діяльність Юрія Івановича була пов'язана саме із цим провідним вищим медичним навчальним закладом держави, де він пройшов шлях від аспіранта до профресора, завідувача Центральної науково-дослідної лабораторії (1986-1987), завідувача кафедри біоорганічної, біологічної та фрармацевтичної хімії (1997-2010).

З 1987 до 1992 р. Ю. І. Губський працював заступником директора з наукової роботи і в. о. директора Київського НДІ фрармакології та токсикології МОЗ України (на даний час - Інститут фармакології та токсикології НАМН України), заснував відділ біохімічної фрармакології ІФТ, де розпочав розробку фундаментальних питань щодо пошкодження клітин за дії ксенобіотиків фоссфор- та хлорорганічного походження.

З 1991 р. Юрій Іванович проводив адміністративну та науково-організаційну роботу в МОЗ, ВАК і НАМН України: заступник голови вченої медичної ради МОЗ України (1991-1992), начальник управління та атестаційного відділу медичних, біологічних, хімічних і аграрних наук ВАК (1992-2000), член Президії ВАК України

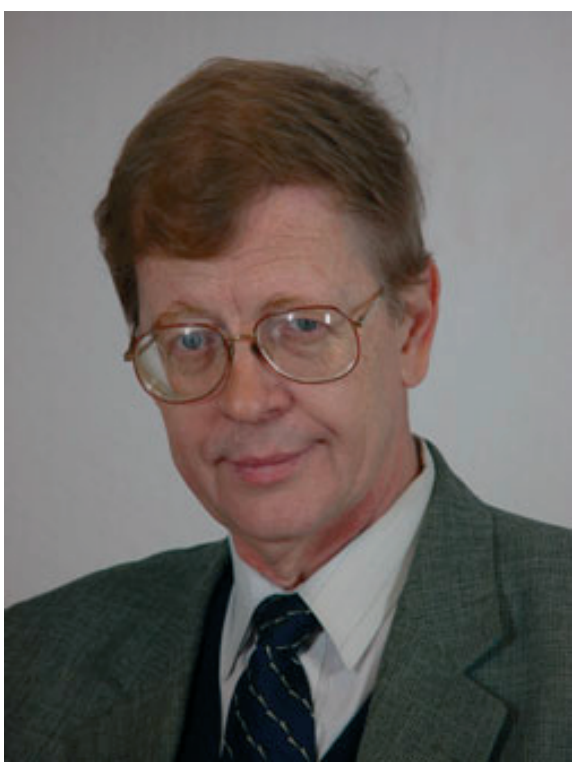

(1992-1997), член Президії НАМН України (1992-1997), перший головний вчений секретар (1993-1996).

Беззаперечним визнанням наукових заслуг Ю. І. Губського стало його обрання в 1994 р. членом-кореспондентом НАМН України. Юрію Івановичу як одному із засновників ВАК України за визначний особистий внесок у створення національної системи атестації наукових та науково-педагогічних кадрів вищої кваліфрікації в Україні в 1997 р. було присвоєно почесне звання заслуженого діяча науки і техніки України.

Як науковець Ю. І. Губський був учнем та послідовником таких видатних українських учених, як один із перших представників школи академіка О. В. Палладіна член-кореспондент АН УРСР А. М. Утевський, доктор біологічних наук, професор Є. Ф. Шамрай, доктор біологічних наук, професор М. Д. Курський. Основними напрямками його багаторічних наукових досліджень стали вивчення молекулярних механізмів пошкодження біомембран та геному клітин печінки і головного мозку, наукове обґрунтування біохімічних та фрармакологічних ефректів антиоксидантів.

Ю. І. Губський і його учні зробили великий науковий внесок у проблему біохімії оксигеназних та вільнорадикальних реакцій у біологічних системах, розв'язання молекулярних механізмів ураження мембран і генетичного апарату клітини за умов активації вільнорадикальних процесів. Пріоритетним напрямком діяльності вченого та наукової школи, яку він очолював, є цикл робіт, присвячених дослідженням апоптотичної загибелі клітин при пошкодженні ДНК високотоксичними біоцидними ксенобіотиками, вивчен- 
ню реакцій ліпопероксидації в ядерному хроматині, ролі іонів кальцію в порушенні метаболічних процесів при антиоксидантній недостатності й дії високотоксичних фрізіологічно активних сполук.

Юрій Іванович - автор перших україномовних підручників для студентів вищих медичних та фрармацевтичного навчальних закладів III-IV рівнів акредитації: "Біологічна хімія", "Біоорганічна хімія", "Bioorganic Chemistry" і навчальних програм для вищих навчальних закладів держави із цих дисциплін.

Член-кореспондент НАМН України Ю. І. Губський - автор близько 750 наукових робіт, у тому числі широко відомих наукових монографій та довідників, зокрема: "Коррекция химического поражения печени” (1989); “Химические катастрофы и экология" (1993); "Лекарственные средства в психофрармакологии” (1997); "Фармакотерапія в паліативній та хоспісній медицині" (2012); “Смерть клетки: свободные радикалы, некроз, апоптоз” (2015). Під його науковим керівництвом підготовлено 19 докторських та 11 кандидатських дисертацій з біохімії, фрармакології і токсикології. Відомими українськими вченими та організаторами медичної науки і вищої медичної освіти є такі учні Юрія Івановича, як доктор біологічних наук, профресор Г. М. Ерстенюк, доктор медичних наук, профресор В. М. Ждан, доктор біологічних наук $€$. Л. Левицький, доктор медичних наук Н. В. Литвинова.

Ю. І. Губський постійно проводив велику науково-організаційну роботу: очолював створену за його ініціативою Проблемну експертну комісію МО3 та НАМН України "Біологічна та медична хімія”, протягом 2004-2010 рр. був головою вперше створеної в нашій державі за його пропозицією та ініціативою спеціалізованої вченої ради Д 26.003.07 “Медична біохімія". Юрій Іванович був членом Наукової ради з теоретичної та просрілактичної медицини НАМН України, членом редакційної колегії "Українського біохімічного журналу" і членом спеціалізованої вченої ради з біохімії та біотехнології Інституту біохімії імені О. В. Палладіна НАН України.

Профресор Ю. І. Губський плідно розвивав актуальні медико-соціальні проблеми паліативної та хоспісної допомоги, питання фрармакологічного знеболювання в паліативній онкології. Він був одним із фундаторів і лідерів у становленні та розвитку паліативної медицини в Україні.

Вічна пам'ять... Сумуємо... Співчуття рідним і близьким... 